\title{
PENGEMBANGAN SISTEM DAN TEKNOLOGI HOME INDUSTRI KANREJAWA BANNANG-BANNANG MELALUI KKN-PPM DI DESA MACCINIBAJI KECAMATAN BATANG KABUPATEN JENEPONTO SULAWESI SELATAN
}

\author{
Siti Suwadah Rimang' dan Syawaluddin Soadiq ${ }^{2}$ \\ 1,2Universitas Muhammadiyah Makassar \\ Email: sitisuwadah@yahoo.co.id
}

\begin{abstract}
The development of society is always related with poverty which happened to half of society. Nowadays, poverty is not only Indonesian problem but also world cases. Indonesia was identically known with its poverty, however deeply inside this country is willingness to develop and grow up. Therefore, to anticipate the increasing of poor society, the government through KKN-PPM opened the opportunity widely to help society by cooperation with university that had qualified human resources. One of them is to help society to improve home industry at target village. It is known that home industry is main role in nation economic that can hold on crisis time. This additional activity helps them to change their life better. This research employed such method to visit the society to be trained, create their groups of home industry, conduct training of good products, labeling, business analysis, business development, exhibition, and study comparative to central industry of Makassar.
\end{abstract}

Keyword: home industry, kanrejawa, bannang-bannang, innovation and technology

\section{PENDAHULUAN}

Perkembangan zaman bukanlah hal yang harus menghilangkan tradisi yang sudah melekat di dalam masyarakat. Akhir merupakan hasil kreatifitas manusia sebagai makhluk berpikir dan bertindak dalam mengembangkan potensi yang dimiliki. Hasil dari kreatifitas juga harus dapat menjaga tradisi yang ada sebelumnya. Karena merupakan upaya kreatifitas para pendahulu kita. Meninggalkan tradisi sebelumnya justru dapat membuat kita kehilangan jati diri atau identitas yang sebenarnya. Pesatnya perubahan menuntut masyarakat mengubah pola hidup menyesuaikan dengan jaman, yang sering kita lalai pada jati diri kita sendiri.

Menurut Pedoman Pelaksanaan Penelitian dan Pengabdian Kepada Masyarakat oleh Perguruan Tinggai yang diterbitkan Direktorat Pembinaan Penelitan dan Pengabdian Kepada Masyarakat (Ditbinlitabmas, $1996: 3$ ), disebutkan bahwa yang dimaksud pengabdian kepada masyarakat adalah pengamalan ipteks yang dilakukan oleh perguruan tinggi secara melembaga melalui metode ilmiah langsung kepada masyarakat (di luar kampusyang tidak terjangkau oleh program pendidikan formal) yang membutuhkannya, dalam upaya mensukseskan pembangunan dan mengembangkan manusia pembangunan. Dengan kata lain, kegiatan pengabdian pada masyarakat oleh perguruan tinggi merupakan pengamalan ipteks secara ilmiah dan melembaga oleh perguruan tinggi dalam upaya pengembangan kemampuan masyarakat untuk mempercepat tercapainya tujuan pembangunan. Pada umumnya kegiatan pengabdian pada masyarakat di perguruan tinggi dikoordinasikan oleh Lembaga Pengabdian kepada Masyarakat (LPM) atau Pusat Pengabdian kepada Masyarakat (PPM). Pengabdian kepada 
masyarakat merupakan tugas perguruan tinggi dengan memanfaatkan, mengembangkan dan menerapkan ipteks dalam rangka memberikan sumbangan atau partisipasi untuk mempercepat pembangunan masyarakat.

Bertambahnya peradaban manusia yang ditandai dengan meningkatnya jumlah penduduk, ilmu pengetahuan, perekonomian maka semakin komplek permasalahan yang dihadapi masyarakat. Permasalahan yang dihadapi tidak hanya untuk memenuhi kebutuhan manusia saja, tetapi juga yang memiliki kebutuhan dan gaya hidup yang selalu meningkat dan berubah-ubah. Pada dasarnya masalah ekonomi berada dalam lingkup produksi, konsumsi, dan distribusi.

Pengembangan sistem adalah metode/prosedur/konsep/aturan yang digunakan untuk mengembangkan suatu sistem informasi atau pedoman bagaimana dan apa yang harus dikerjakan selama pengembangan sistem (algorithm). Metode adalah suatu cara, teknik sistematik untuk mengerjakan sesuatu (Dinu, 2008). Kebutuhan adalah keinginan manusia terhadap benda atau jasa yang dapat memberikan kepuasan jasmani maupun kebutuhan rohani. Kebutuhan manusia tidak terbatas pada kebutuhan yang bersifat konkret (nyata) tetapi juga bersifat abstrak (tidak nyata). Misalnya rasa aman, ingin dihargai, atau dihormati, maka kebutuhan manusia bersifat tidak terbatas. Beberapa faktor yang menyebabkan kebutuhan manusia itu tidak terbatas antara lain sebagai:

1. Makin bertambahnya jumlah penduduk

2. Makin maju ilmu pengetahuan dan teknologi

3. Makin meluaskan lingkungan perguruan

4. Meningkatkan tingkat kebudayaan dan kebutuhan manusia

Dalam pemenuhan kebutuhan manusia yang tidak terbatas dapat dilakukan dengan cara berusaha secara individu atau kelompok dalam masyarakat atau lingkungannya atau pemenuhan kebutuhan tidak sekaligus, tetapi harus menerapkan skala prioritas yaitu mengutamakan kebutuhan yang penting untuk diutamakan. Belshaw (1981:13).

Pendidikan yang merupakan proses pendewasaan dan pemandirian manusia secara sistematis, agar siap menjalani kehidupan secara bertanggung jawab. Kuliah Kerja Nyata Pembelajaran Pemberdayaan Masyarakat (KKN-PPM) merupakan salah satu program dalam pendidikan tinggi di Universitas Muhammadiyah Makassar (UNISMUH). KKN-PPM lahir dari dasar pemikiran bahwa mahasiswa adalah calon sarjana sebagai penerus pembangunan yang juga harus dapat bekerja untuk memecahkan masalah-masalah pembangunan yang ada dalam masyarakat.

Pembangunan dan pengembangan sumber daya manusia memerlukan komitmen yang sangat tinggi dan jangka waktu yang panjang. Proses pengembangan itu merupakan proses pemberdayaan yang sangat sulit, harus dilakukan secara bertahap dan diikuti oleh semua yang terlibat, terutama para peserta yang dibangun, tanpa bisa diwakilkan. Karena kualitas keluarga indonesia yang relative rendah, maka pemberdayaan SDM itu dilakukan dengan pertama-tama, atau minimal sekaligus, memberdayakan keluarga sebagai lembaga yang pertama dan utama dari setiap insan anggotanya. Dalam proses pengembangan anggota keluarganya, maka keluarga akan memegang peranan yang sangat menentukan.

Untuk mengurangi kemiskinan dan pengangguran, yang perlu dilakukan adalah memberdayakan masyarakat. Ini akan lebih efektif dibandingkan hanya memberikan bantuan yang sifatnya sesaat. Yang dibutuhkan adalah pemberian akses kepada masyarakat tersebut. Ini kurang dilakukan pemerintah, pemerintah perlu diberi akses kepada masyarakat dibanding ekonomi, sosial, budaya dan sebagainya. Mereka harus dibantu untuk bisa mencari makan sendiri. Jadi jangan hanya diberi makan. Intinya adalah buatlah program-program pemberdayaan yang berkesinambungan. 
Tak dapat dipungkiri bahwa dari tahun ke tahun pertambahan penduduk semakin meningkat sementara pengangguran dan kejahatan semakin merajalela. Salah satu penyebabnya bisa dilihat faktor pertumbuhan penduduk yang tidak diimbangi dengan pendapatan yang melimpah. Tidak mengagetkan bila terjadi "besar pasak daripada tiang." Inilah pekerjaan rumah bagi perguruan tinggi, masyarakat dan pemerintah sebagai pengambil kebijakan. Semuanya hasul mampu saling bekerja sama untuk mewujudkan negara sejahtera.

Kemiskinan dan pengangguran menjadi masalah yang penting saat ini di Indonesia, sehingga menjadi suatu fokus perhatian bagi pemerintah Indonesia. Masalah kemiskinan ini sangatlah kompleks dan bersifat multidimensional, dimana berkaitan dengan aspek sosial, ekonomi, budaya, dan aspek lainnya. Kemiskinan terus menjadi masalah fenomenal di belahan dunia, khususnya Indonesia yang merupakan Negara berkembang. Kemiskinan telah membuat jutaan anak tidak bisa mengenyam pendidikan, kesulitan membiayai kesehatan, kurangnya tabungan dan investasi, dan masalah lain yang menjurus ke arah tindakan kekerasan dan kejahatan.

$\mathrm{Di}$ dalam proses peningkatan sumber pendapatan masyarakat desa Maccinibaji melalui home industri, seharusnya dibangun penyadaran akan pentingnya sebuah perubahan hidup. masyarakat tidak boleh terpaku pada satu pendapatannya saja.

Selama ini, banyak program pembangunan dari pemerintah yang telah dilakukan dalam rangka mengurangi kemiskinan seperti Inpres Desa Tertinggal (IDT), pemberian Bantuan Langsung Tunai (BLT), Raskin, Kompensasi BBM, dan lainlain. Namun, dari program yang telah dilaksanakan oleh pemerintah tersebut masih terdapat kekurangan-kekurangan dalam pelaksanaannya dan belum mampu mengurangi tingkat kemiskinan di Indonesia serta dinilai kurang efektif, karena masyarakat hanya menerima bantuan langsung dan tidak ada partisipasi aktif dari masyarakat itu sendiri dalam upaya memperbaiki dan meningkatkan kondisi kehidupan mereka.

Dengan adanya home industri besar peluang masyarakat dapat Meningkatnya kemampuan keuangan rumah tangganya. Meningkatnya pertumbuhan ekonomi masyarakat desa akan terjadi pemerataan pendapatan, melalui penguatan dan perluasan jaringan pasar lokal serta optimalisasi produk.

Untuk mengurangi kemiskinan dan pengangguran, yang perlu dilakukan adalah memberdayakan masyarakat. Ini akan lebih efektif dibandingkan hanya memberikan bantuan yang sifatnya sesaat. Yang dibutuhkan adalah pemberian akses kepada masyarakat tersebut. Ini kurang dilakukan pemerintah, pemerintah perlu diberi akses kepada masyarakat dibanding ekonomi, sosial, budaya dan sebagainya. Mereka harus dibantu untuk bisa mencari makan sendiri. Jadi jangan hanya diberi makan. Intinya adalah buatlah program-program pemberdayaan yang berkesinambungan.

\section{METODE}

Metode yang digunakan dalam pemberdayaan kelompok sasaran adalah:

1. Kunjungan kelompok

2. Diskusi kelompok (mengetahui keinginan kelompok sasaran)

3. Pratik pembuatan home industri (menyesuaikan keinginan kelompok sasaran)

4. Promosi hasil kerja kelompok sasaran

5. Membuatkan label kemasan yang menarik Program ini dilaksanakan oleh masyarakat dan untuk masyarakat itu sendiri dengan mendapatkan pendampingan dari mahasiswa KKN-PPM yang ditugaskan oleh Perguruan Tinggi.

Berdasarkan hasil observasi, maka perencanaan pelaksanaan program dapat dilakukan dengan langkah-langkah sebagai berikut: 
1. Mengindentifikasi ibu-ibu yang memiliki motivasi besar untuk berubah yang berada di desa Maccinibaji, kecamatan Batang Kabupaten Jeneponto Sulawesi Selatan.

2. Mengidentifikasi Membuat validasi data wanita rawan sosial ekonomi yang berhak untuk mendapatkan program bantuan

3. Mempersiapkan tutor, peralatan dan tempat untuk diadakan pelatihan

4. Sosialisasi program kepada seluruh warga masyarakat Desa Maccinibaji mengenai pelaksanaan kegiatan.

5. Wanita rawan sosial ekonomi yang sudah terpilih ditempatkan dalam satu kelompok bertujuan agar proses pelatihan dapat berjalan lancar dan tanpa hambatan yang berat

6. Pendampingan diadakan selama 2 bulan penuh dengan keterangan waktu pelatihan dan praktek disesuaikan dengan luangnya para ibu-ibu kelompok

7. Pelaksanaan pelatihan menggunakan sistem pembelajaran terbuka yang memungkinkan peserta untuk bereksplorasi dan berimprovisasi sesuai dengan kreatifitas dan keahliannya sendiri dalam mengolah bahan yang telah disiapkan.

8. Pelatihan juga disertai dengan materi tentang manajemen usaha dan pemasaran produk sehingga nantinya selain skill membuat Kanrejawa Bannangbannang, peserta juga memiliki soft skill dalam bidang manajemen

9. Diadakan sesi untuk bertukar pendapat (konseling kelompok) guna saling menguatkan diantara sesama meraka dan juga untuk menambah semangat dalam menjalani kehidupan dan memiliki visi untuk maju ke depan.

10. Melakukan pameran kue Bannangbannang sebagai ajarang promosi sekaligus mencari rasa dan buatan yang berbeda di antara kelompok itu.

11. Studi banding ke Centra Home Indondustri.
Perencanaan jangka panjang dan tindak lanjut program yang berhubungan dengan home industri ini, adalah terus melakukan pembinaan hingga suatu saat home industri ini merupakan sebuah home industri yang layak menjadi percontohan bagi desa.

Perekonomian di desa tidak hanya berfokus pada masalah pertanian semata, tetapi lebih dari itu termasuk pada sektor jasa dan industri, serta perdagangan namun tetap berfokus pada karakter dan potensi desa yang dimaksud. Hal ini berarti bahwa ekonomi desa dapat dipacu melalui ketersediaan sumber daya alam yang dikelola oleh sumber daya manusia yang merupakan elemen penting dalam sektor perekonomian desa.

Industri rumah tangga (Home industri) merupakan salah satu unit usaha yang terdapat di desa. Industri rumah tangga atau industri rumahan merupakan industri dalam skala kecil. Dalam kondisi terbatas seperti itu, maka out put yang dihasilkan oleh industri rumah tangga juga relatif kecil. Padahal industri rumah tangga juga dapat berkembang menjadi industri menengah atau industri besar jika dikelolah dengan maksimal.

Meskipun industri rumah tangga dikategorikan sebagai industri kecil, tetapi bagaimana pun juga dalam proses atau aktivitas sehari-hari industri ini melibatkan tenaga kerja yang mayoritas berasal dari desa setempat (desa dimana lokasi industri itu berada). Penyerapan tenaga kerja ini jelas menciptakan situasi

yang positif, dimana secara tidak langsung keberadaan industri ini telah membuka lapangan kerja bagi masyarakat sekitar.

Mengenai industri kecil atau yang lazim disebut industri rumah tangga (home industry), biasanya dilakukan atau diproses dalam space yang kecil atau terbatas, seperti modal yang tidak terlalu besar, teknologi yang juga tidak terlalu modern, termasuk tenaga kerja yang biasanya berasal dari keluarga sendiri. Walaupun ada tenaga bantuan dari luar, jumlahnya tidak banyak. Karena berproses dalam skala yang terbatas, maka outputnya pun tidak banyak, seperti yang dihasilkan oleh industri besar/raksasa. Tetapi 
mengenai mutu/kualitas tentu tidak dapat dikatakan selalu jelek karena banyak industri kecil yang sangat menjaga mutu produknya demi menjaga image merekadi pasaran.

Dengan demikian, kesejahteraan masyarakat desa Maccinibaji juga akan nampak. Rencana yang paling besar adalah mampu mengirim produk ke seluruh wilayah Indonesia dan tentu telah memiliki label dan perizinan dari departemen perdagangan.

\section{HASIL DAN PEMBAHASAN}

\section{A. Sekilas Kanrejawa Bannang-bannang}

Bentuknya seperti benang yang dijalin silang-menyilang, rapi, namun sangat sulit untuk dipisahkan. Mungkin itulah alasan mengapa masyarakat memberinya namanya Bannang-bannang, yang dalam bahasa Makassar artinya benang-benang.

Banyak orang yang berpikir cara membuat kanrejawa banning-bannang ini amat rumit. Karena harus menjalinnya satu persatu sampai terbentuk sesuai hasil yang diinginkan serta membutuhkan ketekunan dan kerapian tingkat tinggi.

Ternyata setelah kami perhatikan justru sangat mudah. Adonan yang terbuat dari tepung beras hanya perlu dimasukkan dalam batok kelapa yang dibentuk menyerupai timba (dengan pegangan), dan bagian bawahnya dilubangi untuk keluarnya adonan yang berbentuk cair. Setelah minyak goreng dalam wajan telah panas, maka cairan dimasukkan seperti membuat kue dadar, dilipat dalam minyak berbentuk segi empat (atau segitiga, sesuai keinginan). Diangkat saat kue sudah berwarna, didinginkan, lalu disiram gula merah yang telah dilelehkan atau dengan pewarna makanan yang diinginkan.

Dalam Budaya Tutur bahasa Makassar Kanrejawa Bannang-bannag memiliki pengertian mendalam akan makna kehidupan, seperti yang biasa di dengar dari orangtua melalui tuturannya seperti, "Angtu BannangBannanga Nak, Kanrejawa Karaeng, Kasaba' tani asseng pokokna, tani asseng cappana, rellaki tani asseng manna mamo te'ne naerang...(kurang lebih bermakna seorang manusia Karaeng (Bangsawan), tak terlalu mempermasalahkan.. apakah orang tahu atau tidak siapa dia, dan dia ikhlas akan hal itu, dia tak terlalu mempermasalahkan walau jelasjelas manis yang dibawa dalam masyarakat... kue ini bagai benang kusut...boleh jadi setiap manusia kebanyakan akan mempertanyakan asal usulnya, namun kepada dirinya dia tahu bahwa Sang Maha menciptakannya tahu siapa dia sebenarnya..)

\section{B. Hasil Pengabdian KKN-PPM dalam Pendampingan Kelompok}

Hasil pengabdian kami memberi dampak yang sangat besar bagi mahasiswa dan masyarakat untuk terus mengembangkan home industri kanrejawa bannang-bannang.

Untuk mendapatkan inovosi kanrejawa bannang-bannang bagi kami tidaklah mudah baik dari segi bentuk, warna dan rasa. Karenajwa Bannang-bannang ini awalnyanya hanya berwarna coklat saja dan hanya memiliki satu rasa yakni rasa gula merah. dengan berbagai usaha kami berusaha mengubah kanrejawa bannang-bannang ini dengan berbagai rasa, model, dan warna.

Sampai saat ini, kami terus berupaya mendapatkan perizinan dari dinas kesehatan untuk makanan khas Jeneponto, sehingga makanan ini layak menjadi menu bagi masyarakat luas. Yang pada akhirnya satu makanan lokal menjadi lestari sepanjang masa.

Kegagalan yang berulang-ulang tentu membuat kami mengerti bahwa pasti ada keberhasilan. Dan kami merasakan bahwa inovasi kami mendapat apresiasi yang luarbiasa dari dinas Koperasi Usaha Kecil dan Menengah, dan dari Dinas perdagangan dan Perindutrian kabupaten Jeneponto.

Sampai saat ini, kami terus berupaya mendapatkan perizinan dari dinas kesehatan untuk makanan khas Jeneponto, sehingga makanan ini layak menjadi menu bagi masyarakat luas. Yang pada akhirnya satu makanan lokal menjadi lestari sepanjang masa.

Tentu kami harus berbesar hati untuk mendapatkan pesaing-pesaing dikemudian 
hari. Oleh karena itu, kami berusaha mengidentifikasi terhadap kekuatan, kelemahan, peluang, dan ancaman di UKM sektor Home industri pengolahan Kanrejawa bannang-bannang ini. kemudian dilanjutkan dengan pembuatan matrik SWOT untuk menentukan alternatif strategi. Matrik ini menggambarkan bagaimana peluang dan ancaman eksternal yang dihadapi oleh UKM home industri pengolahan Kanrejawa bannang-bannang yang disesuaikan dengan kekuatan dan kelemahan yang dimiliki oleh UKM Home industri pengolahan Kanrejawa bannang-bannang.

Tentu kami harus berbesar hati untuk mendapatkan pesaing-pesaing dikemudian hari. Oleh karena itu, kami berusaha mengidentifikasi terhadap kekuatan, kelemahan, peluang, dan ancaman di UKM sektor Home industri pengolahan Kanrejawa bannang-bannang ini. kemudian dilanjutkan dengan pembuatan matrik SWOT untuk menentukan alternatif strategi. Matrik ini menggambarkan bagaimana peluang dan ancaman eksternal yang dihadapi oleh UKM home industri pengolahan Kanrejawa bannang-bannang yang disesuaikan dengan kekuatan dan kelemahan yang dimiliki oleh UKM Home industri pengolahan Kanrejawa bannang-bannang.

\section{KESIMPULAN DAN SARAN}

\section{A. Kesimpulan}

Simpulan yang didapat ditarik dari hasil pengabdian ini pada tahun pertama ini, adalah dibutuhkannya motivasi akan pentingnya keberadaan home industri yang pada akhirnya akan menambah pendapatan dan mengurangi kemiskinan.

Dibutuhkannya pendampingan yang terusmenrus kepada kelompok-kelompok sasaran. Hingga akhirnya mereka mampu berdiri sendiri. Ini akan lebih efektif dibandingkan hanya memberikan bantuan yang sifatnya sesaat. Yang dibutuhkan adalah pemberian akses kepada masyarakat seluas-luasnya agar masyarakat merasa mendapat perhatian.

\section{B. Saran}

Hasil pengabdian ini terkait dengan potensi pedesaan yakni di desa Maccinibaji, kecamatan Batang, Kabupaten Jeneponto Sul-Sel. Berdasarkan hasil pengabdian selama berada di tengah-tengah kelompok Pembuat Kanrejawa Bannang-bannang, maka beberapa saran dalam bentuk rekomendasi kepada:

1. Pemda Jeneponto terkait kebijakan terhadap pengembangan home industri khususnya Kanrejawa Bannang-bannang sebagai salah satu cemilan khas Makassar yang perlu untuk dilestarikan dalam meningatkan taraf hidup masyarakat.

2. Pendamping kelompok KKN-PPM kiranya tetap memelihara semangat untuk terus memberi informasi dan membantu masyarakat untuk mempromosikan hasilhasil produksinya.

3. Dinas Perdagangan dan Perindustrian Kabupaten Kota kiranya dapat memberi pembinaan khsusus dalam mengembangkan kualitas kue-kue tradisional.

4. Dinas Koperasi dan UKM Kabupaten Kota kiranya setiap ada even-even perlombaan atau pameran mengikutsertakan kelompok pembuat Kanrejawa bannang-bannang binaan KKN-PPM Unismuh Makassar.

\section{DAFTAR PUSTAKA}

Basrowi. 2005. Pengantar Sosiologi. Bogor: Ghalia Indonesia

Belshaw Cyril, S. 198I. Tukar Menukar Tradisional dan Pasar Modern. Jakarta: PT Gramedia

Budi Sutedjo dan Dharma Oetomo 2002. Perancangan \& Pengembangan Sistem Informasi, Yogyakarta: Andi press.

Damsar. 2002. Sosiologi Ekonomi. Jakarta: PT. Raja Grafindo Persada

Ditbinlitabnas (1996) Pedoman Pelaksanaan Penelitian dan Pengabdian Kepada Masyarakat Oleh Perguruan Tinggi, Ditjen Dikti, Jakarta : Depdikbud

Joyomartono, Mulyono. 1989. Perubahan Kebudayaan dan Masyarakat Dalam Pembangunan. Semarang: IKIP Semarang Press 
Koentjaraningrat. 1993. Metode-metode Penelitian masyarakat. Jakarta: Gramedia Pustaka Utama

Pasaribu J.L dan Simadjuntak. 1982. Sosiologi Pembangunan. Bandung: Tarsito

Seokanto, Soerjono. 2002. Sosiologi Suatu Pengantar. Jakarta: PT. Raja Grafindo Persada

Solomon, Michael R. 2002. Consumer Behavior: Buying, Having and Being, edition. New Jersey: Prentice Hall, inc

Sukijo . 2000. Tujuan dan Khalayak PPM. Jurnal Aplikasi Ilmu-ilmu Agama, Vol. I, No. I Desember 2000:62-78. 